TAO, Vol. 16, No. 1, 1-17, March 2005

\title{
Age Model and Oxygen Isotope Stratigraphy of Site ODP1202 in the Southern Okinawa Trough, Northwestern Pacific
}

\author{
Kuo-Yen Wei ${ }^{1, *}$, Horng-Sheng Mii ${ }^{2}$ and Chi-Yue Huang ${ }^{3}$
}

(Manuscript received 2 January 2004, in final form 31 March 2004)

\begin{abstract}
The two sedimentary sequences drilled at Holes 1202B and 1202D were correlated based upon direct lithologic observation, shipboard logging of magnetic susceptibility, and bulk density to form a stacked record of $410 \mathrm{~m}$ in length. Calcareous nannofossil and planktic foraminiferal occurrences confine the bottom of the record to be younger than $85 \mathrm{ka}$, whereas the sediments in the interval $\mathbf{2 2 5}-\mathbf{2 8 0}$ mbsf in Hole 1202D are apparently of turbidite origin. Eleven AMS carbon-14 datings of planktic foraminifera and scaphopod samples from Hole 1202B suggest that the upper $110 \mathrm{~m}$ has a continuous record dating back over the past 28 thousand years.

An oxygen isotope stratigraphy based upon planktic foraminifera Neogloboquadrina dutertrei was established from the stacked sequence. The upper part of the $\delta{ }^{18} \mathrm{O}$ profile can be well correlated to that from the central Okinawa Trough site DGKS9603 (Li et al. 2001) in both trend and absolute values whereas the lower part is considered to belong to marine oxygen isotope stage 4 . The sedimentation rates have been always high at this site, ranging from 1.5 to 16 meters per thousand years.
\end{abstract}

(Key words: Age model, Oxygen isotope stratigraphy, Okinawa Trough, Quaternary)

\section{INTRODUCTION}

The two eyes of history are geography and chronology.

James A. Carfield (1831 - 1881)

\footnotetext{
${ }^{1}$ Department of Geosciences, National Taiwan University, Taipei, Taiwan, ROC

2 Department of Earth Sciences, National Taiwan Normal University, Taipei, Taiwan, ROC

${ }^{3}$ Department of Earth Sciences, National Cheng Kung University, Tainan, Taiwan, ROC

* Corresponding author address: Prof. Kuo-Yen Wei, Department of Geosciences, National Taiwan University, Taipei, Taiwan, ROC; E-mail: weiky@ntu.edu.tw
} 
By its very nature that younger sediments were superimposed on the older ones, sedimentary record provides a direct record of events in chronological order, yet, only in a relative sense. To know the exact rate of changes recorded in a sedimentary sequence, one needs to have knowledge of absolute dates of such events. To decipher the lead and lag of events recorded in different sequences and regions, one ought to make precise age determination and correlation among different records. Before inferring any evolutionary scenarios for a sedimentary record under investigation, a major challenge has always been how to establish a reliable chronological framework.

The main thrust of this paper is to establish a chronological framework for two cores obtained from the ODP Site 1202, Leg 195 in the Okinawa Trough, northwest Pacific (Fig. 1). Site 1202 was designed to obtain a high-resolution record of paleoceanographic changes of the Kuroshio during the late Quaternary from the southern slope of the southernmost Okinawa Trough. A total of four holes were drilled from a water depth of $1274 \mathrm{~m}$ at $24^{\circ} 48^{\prime} \mathrm{N}, 122^{\circ} 30^{\prime} \mathrm{E}$. The sedimentary sequences obtained from the four holes vary from $97.5 \mathrm{~m}$ to $410 \mathrm{~m}$ in length (Fig. 2).

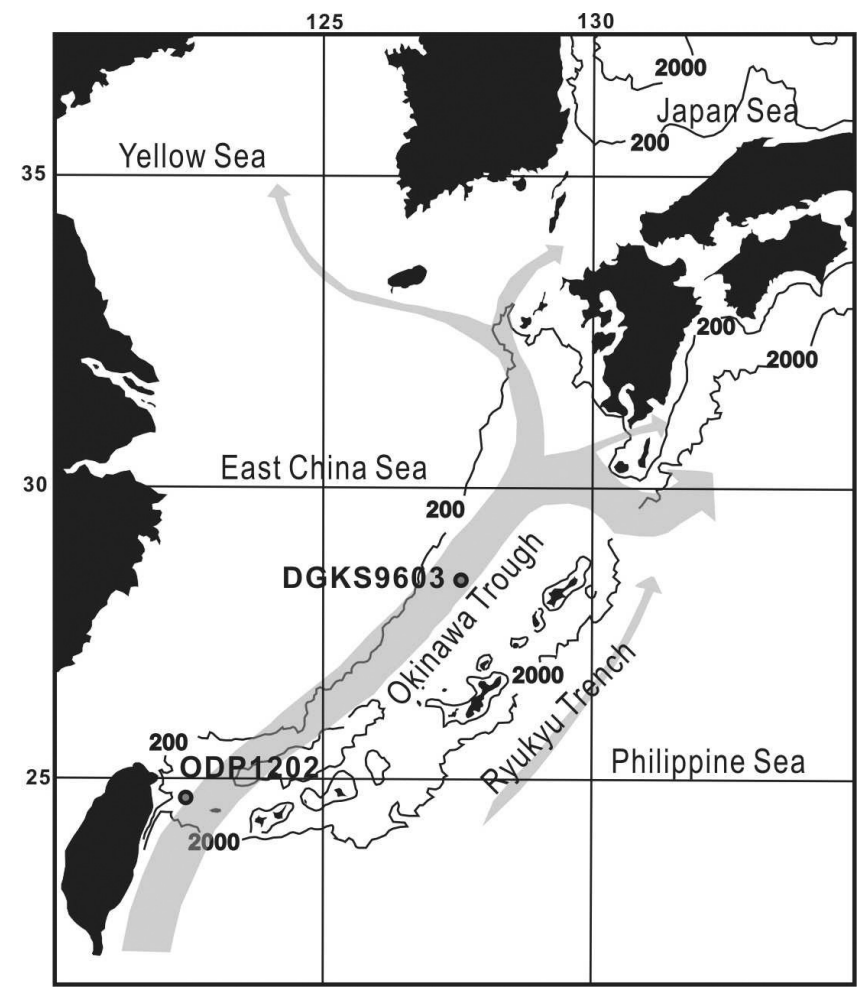

Fig. 1. Locations of two sedimentary cores (ODP1202 and DGKS9603) discussed in this study in the Okinawa Trough. Both sites are distributed along the main path of Kuroshio marked by the gray belt. Contour lines: $200 \mathrm{~m}$ and $2000 \mathrm{~m}$ in depth. 

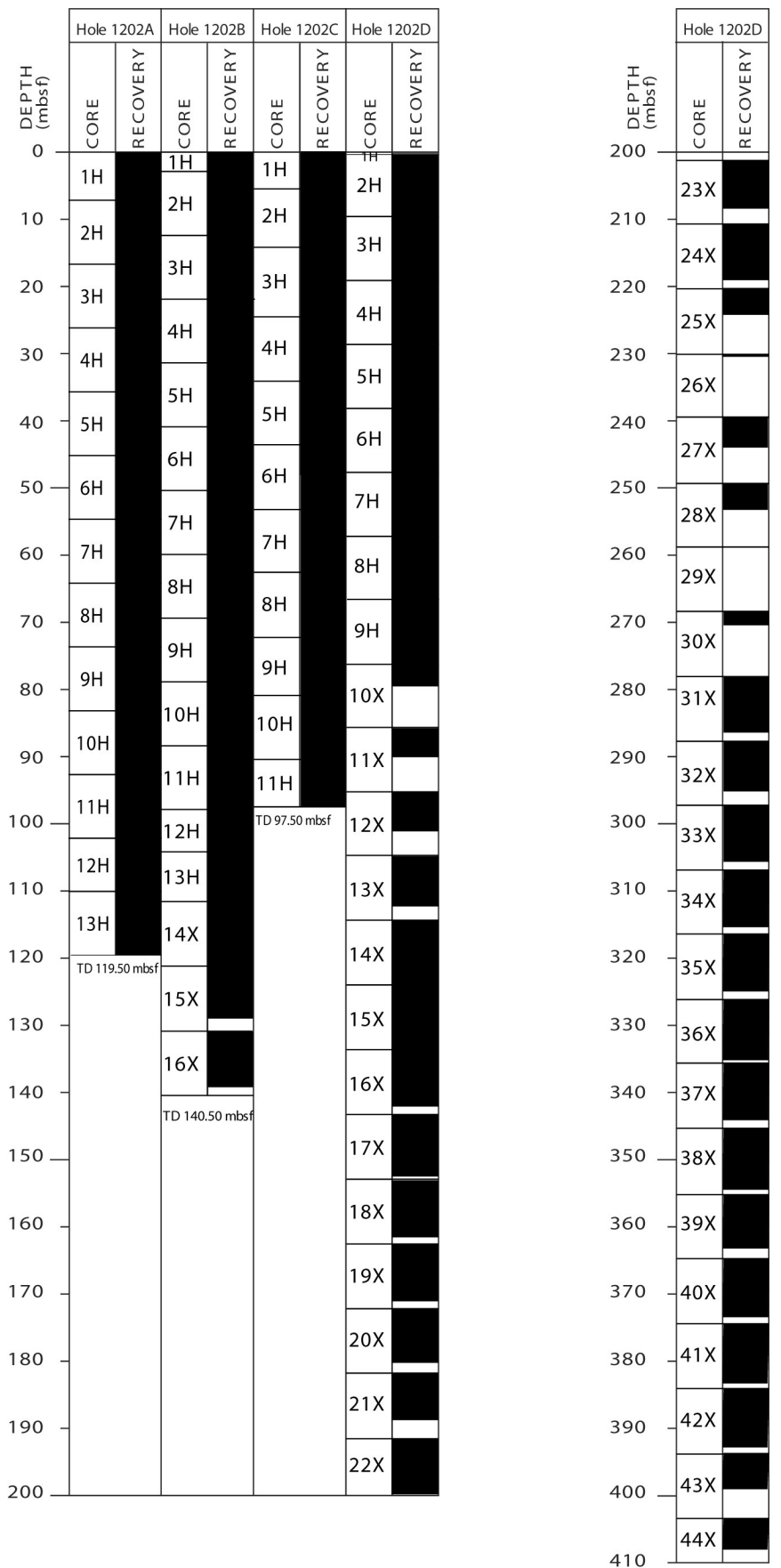

Fig. 2. Recovery of sedimentary sequences by Advanced Piston Cores (abbreviated by $\mathrm{H}$ ) and Extended Core Barrels (X) in ODP Holes 1202B and 1202D. The core depths are recorded as meters below sea floor (mbsf). 
Because time constraints did not permit a splicing of the sedimentary sequences cored from the four holes using shipboard measurements of physical properties, all the cores are reported in terms of meters below sea floor (mbsf) instead of composite depth. Only the intervals within $0-140$ mbsf of the four holes were run through the Multisensor Track (MST) during Leg 195 whereas the lower sections recovered from depths between 140 and 410 mbsf in Hole 1202D were run through the MST during Leg 196. The MST measured volume magnetic susceptibility (MSL), density using gamma ray attenuation (GRA), and $P$-wave velocity (Shipboard Scientific Party 2002). A comparison of the GRA bulk density measurements made during Legs 195 and 196 on samples from Hole 1202D suggests that the measurements made during Leg 196 were not reliable. The bulk density values were $\sim 0.3-0.5 \mathrm{~g} \mathrm{~cm}^{-3}$ lower than the Leg 195 measurements for the same depths $(0-140 \mathrm{mbsf})$. The reduction of density is apparently caused by desiccation or pooling of water (Shipboard Scientific Party 2002). The magnetic susceptibility and density profiles show an excellent correlation between holes on a scale of meters, but the noise caused by gas expansion voids precluded correlation at smaller scales $(<1 \mathrm{~m})$, and therefore, these holes could not be spliced to make a composite record (Shipboard Scientific Party 2002). It was decided that Holes 1202B and 1202D were to be sampled for all post-cruise studies.

This study attempts to correlate the top 140 meters of these two holes using lithologic and physical properties. In addition, an age model is established for the stacked sequence based upon carbon-14 dating and oxygen isotope stratigraphy of biogenic carbonates.

\section{MATERIAL AND METHODS}

\section{Correlation between Holes 1202B and 1202D}

A detailed observation of lithologic variation of Holes 1202B and 1202D was conducted at the ODP Gulf Repository, Texas A \& M University (see Huang et al. 2005). Unique occurrences of pumice, layers of concentrated echinoderm spines and enriched pelecypoda were employed as lithologic markers for correlation. For instance, a pumice layer was observed at $85.03 \mathrm{~m}$ in Hole 1202B, correspondingly the highest magnetic susceptibility of about $6000 \times 10^{-5}$ (SI units) was recorded by the MST at about the same depth (note that this peak value is off the scale of Fig. 3). This particular layer of pumice with high magnetic susceptibility was also observed at the depth of $79.56 \mathrm{~m}$ in Hole 1202D (Fig. 3).

In addition, profiles of volume magnetic susceptibility and density (derived from gammaray attenuation) were used to assist correlation. Magnetic susceptibility is the degree to which a material can be magnetized by an external magnetic field; it, in turn, is a function of the amount and kind of magnetic minerals in a sample. Magnetic susceptibility thus reflects lithologic variation. In this study, it was measured at $5-\mathrm{cm}$ intervals along the core providing a high-resolution record.

The bulk density was gauged by the GRA densiometer of the MST system by measuring the attenuation of gamma rays traveling through the core from a ${ }^{137} \mathrm{Cs}$ source (Shipboard Scientific party 2002). The noise introduced by the gas voids and XCB drilling disturbance 


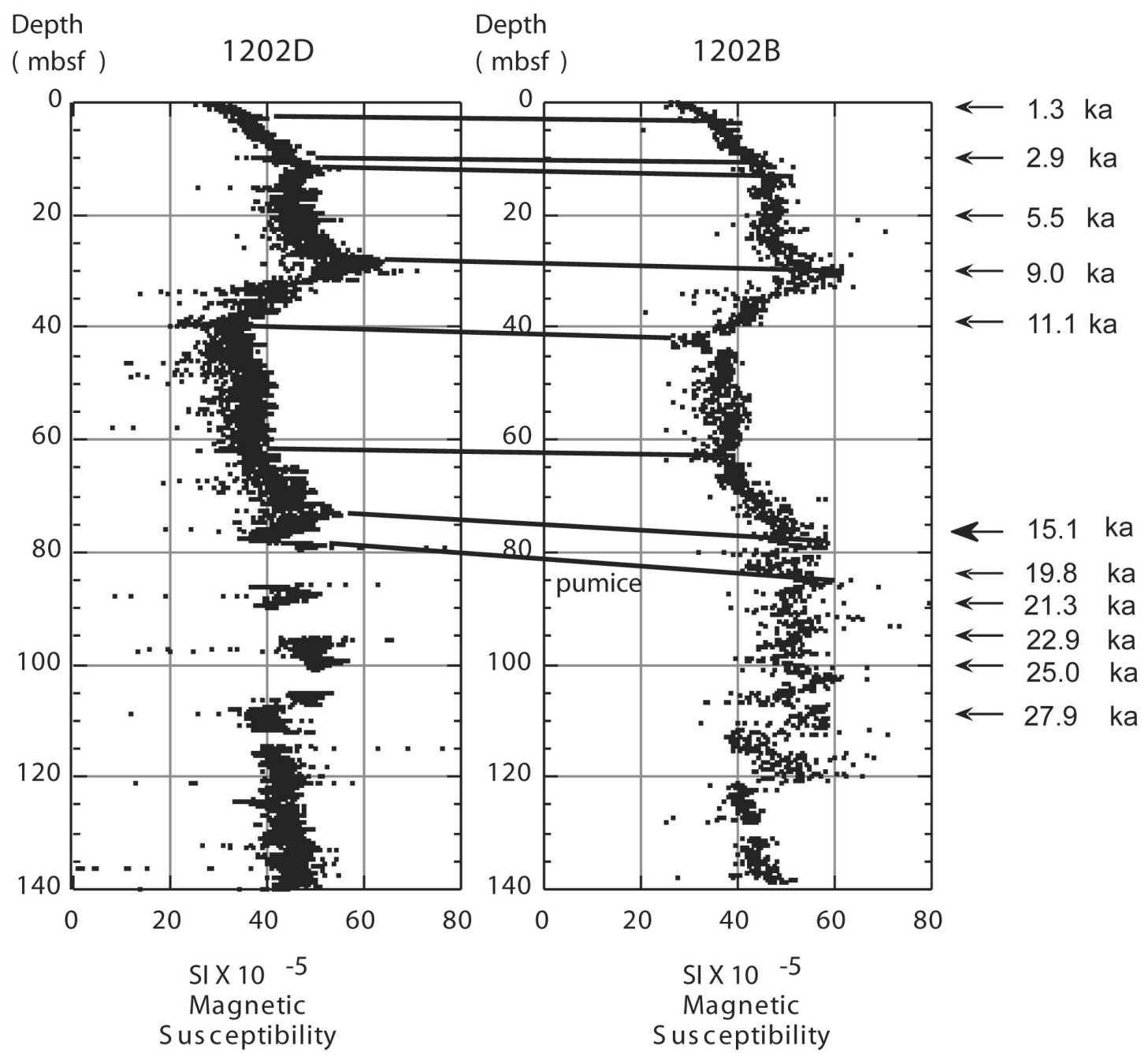

Fig. 3. Correlation between ODP Holes 1202B and 1202D based upon volume magnetic susceptibility. The raw data were adopted from on board measurements during Leg 195 (Shipboard Scientific Party 2002). The pumice layer was marked by high magnetic susceptibility (off the limit of the plots) and validated by direct observation of the core during a post-cruise examination. Also marhed are Carbon-14 dates in thousand years (ka) of calendar age for Hole B.

has made the correlation difficult at scales of $<1 \mathrm{~m}$. As a result, we used only the highest density values as the best estimates for the bulk density of the measured sediments (Fig. 4).

Correlations between these two holes were made separately based upon the above-mentioned criteria or profiles. Most of the correlation lines are consistent among the three sets (Figs. 3 and 4), while the discrepant ones were then evaluated individually. Those correlation 
lines that show the best consistency were retained and listed in Table 1. For instance, the pumice layer at $\sim 85$ mbsf in Hole 1202B shows the highest magnetic susceptibility and a generally low range of bulk density (Figs. 3 and 4), the corresponding interval in Hole 1202D is positioned at $\sim 79$ mbsf just above a coring break. The four coring breaks in the interval 80 - 115 mbsf in Hole 1202D make it difficult to correlate the sequence with Hole 1202B. We

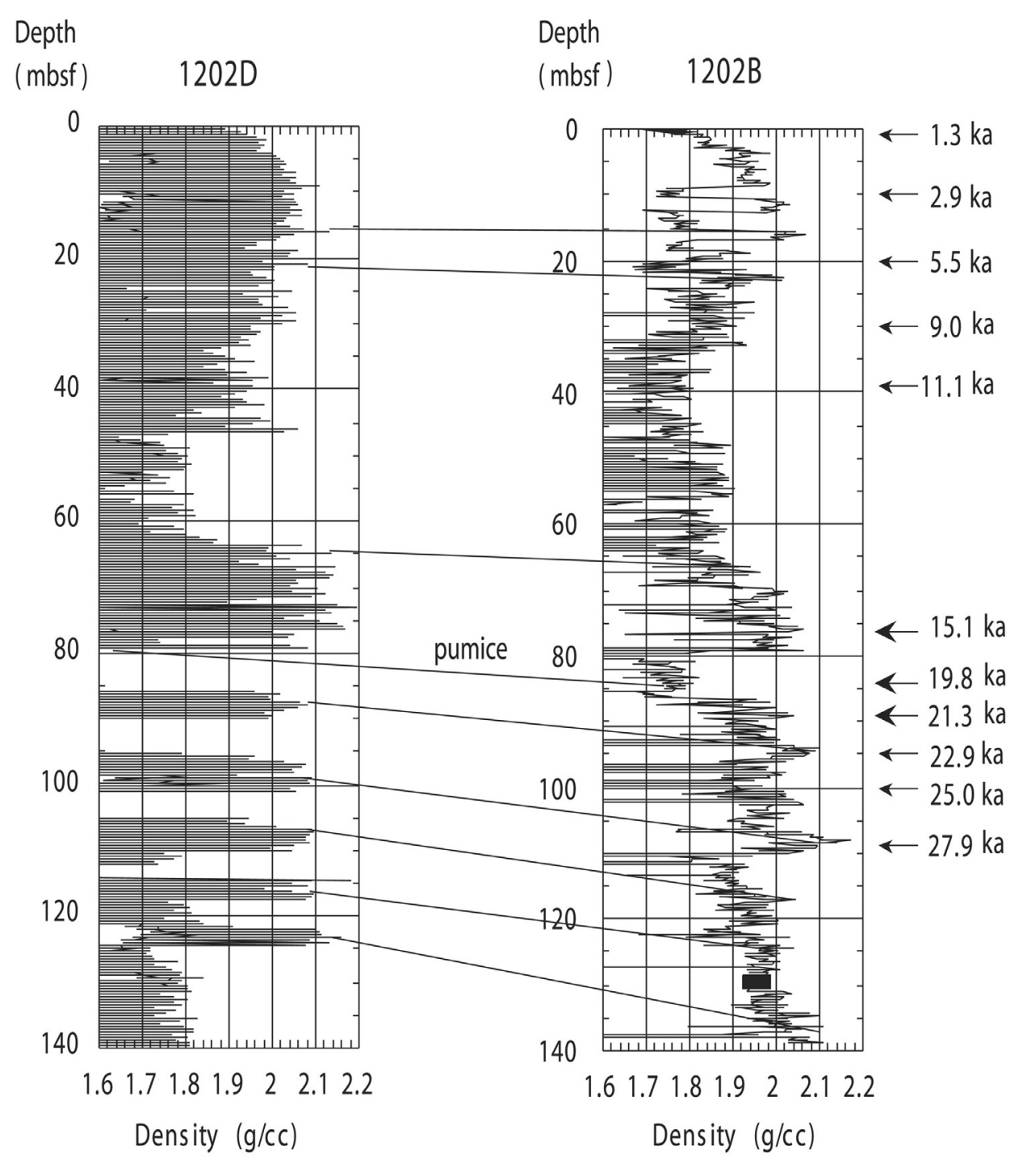

Fig. 4. Correlation between ODP Holes 1202B and 1202D based upon characteristics of bulk density measured by the GRA densiometer of the MultiSensor Track (MST) system on board Leg 195 (Shipboard Scientific party 2002). The pumice layer serves as a benchmark marker. Also marhed are Carbon-14 dates in thousand years (ka) of calendar age for Hole B. 
Table 1. Correlation tie-points between Holes 1202B and D and corresponding ages in Hole 1202B.

\begin{tabular}{llll} 
MD1202B & MD1202D & Marker & Calendar age BP \\
\hline $3.65 \mathrm{~m}$ & $2.86 \mathrm{~m}$ & mag. suscep. peak & $1.60 \mathrm{ka}$ \\
$11.50 \mathrm{~m}$ & $11.44 \mathrm{~m}$ & mag. suscep. peak & $3.05 \mathrm{ka}$ \\
$16.20 \mathrm{~m}$ & $16.10 \mathrm{~m}$ & density peak & $4.33 \mathrm{ka}$ \\
$22.40 \mathrm{~m}$ & $20.90 \mathrm{~m}$ & density peak & $6.10 \mathrm{ka}$ \\
$22.79 \mathrm{~m}$ & $21.08 \mathrm{~m}$ & echinoderm-rich & $6.23 \mathrm{ka}$ \\
$27.11 \mathrm{~m}$ & $26.04 \mathrm{~m}$ & pelecypod-rich & $7.61 \mathrm{ka}$ \\
$30.20 \mathrm{~m}$ & $29.92 \mathrm{~m}$ & mag. suscep. peak & $8.60 \mathrm{ka}$ \\
$42.05 \mathrm{~m}$ & $40.00 \mathrm{~m}$ & mag. suscep. minimum & $11.36 \mathrm{ka}$ \\
$50.05 \mathrm{~m}$ & $48.78 \mathrm{~m}$ & mag. suscep. minimum & $12.21 \mathrm{ka}$ \\
$63.55 \mathrm{~m}$ & $62.00 \mathrm{~m}$ & mag. suscep. peak & $13.65 \mathrm{ka}$ \\
$66.31 \mathrm{~m}$ & $64.80 \mathrm{~m}$ & density peak & $13.94 \mathrm{ka}$ \\
$78.60 \mathrm{~m}$ & $73.20 \mathrm{~m}$ & mag. suscep. peak & $16.01 \mathrm{ka}$ \\
$85.03 \mathrm{~m}$ & $79.56 \mathrm{~m}$ & pumice layer & $20.18 \mathrm{ka}$ \\
$94.10 \mathrm{~m}$ & $87.80 \mathrm{~m}$ & density peak & $22.43 \mathrm{ka}$ \\
$108.10 \mathrm{~m}$ & $99.20 \mathrm{~m}$ & density peak & $27.53 \mathrm{ka}$ \\
$117.20 \mathrm{~m}$ & $107.20 \mathrm{~m}$ & density peak & $28.61 \mathrm{ka}$ \\
$124.40 \mathrm{~m}$ & $117.00 \mathrm{~m}$ & density peak & $29.41 \mathrm{ka}$ \\
$136.20 \mathrm{~m}$ & $123.00 \mathrm{~m}$ & density peak & $31.74 \mathrm{ka}$ \\
& & & \\
\hline & & &
\end{tabular}

assumed that Hole 1202D recovered only high-density materials (silt and clay) via the Extended Core Barrel (XCB), and therefore, the recovered sections were correlated to the intervals of high bulk density in Hole 1202B (Fig. 4). Magnetic susceptibility was used to make further constrains and to assist in correlation. Consequently, the interval between 125 and $140 \mathrm{mbsf}$ in Hole 1202D is of low density and finds no corresponding interval in Hole 1202B.

\section{AMS C-14 Dating}

Samples were obtained from the ODP Repository every $1.5 \mathrm{~m}$ from Hole 1202B (0.5 $142 \mathrm{mbsf}$ ) and 1202D (143.9 - $407.0 \mathrm{~m})$. More than 300 specimens of surface-water dwelling planktic foraminfera, including Globigerinoides spp. and Orbulina universa, were picked exhaustively from the $>250 \mu$ size fraction of 10 selected intervals where there were sufficient foraminifera. For sample 1202B 1H2W-36-47 cm (1.92 mbsf), a scaphopod was picked for analysis. $\mathrm{CO}_{2}$ gas, yielded from the picked specimens, was sent to the Rafter Radiocarbon Laboratory, Institute of Geological and Nuclear Sciences, New Zealand for AMS dating. The 
reported C-14 ages were converted to "calendar ages" using the CALIB rev 4.4 Program (http:/ /radiocarbon.pa.qub.ac.uk/calib/). In the conversion, we adopted a $\Delta \mathrm{R}=35 \pm 25$ years (the local difference in reservoir age from 400 years in the southern Okinawa Trough) as determined from annually banded corals of Ishigaki Island (Hideshima et al. 2001). The calibrated ages were then converted into thousand years BP (ka before AD1950) (Table 2). For those conventional radiocarbon ages older than 20,265 yrBP, the dates were converted to calendar ages using the polynomial equation of Bard et al. (1998):

$[$ cal BP $]=-3.0126 \times 10^{-6} \times\left[{ }^{14} \mathrm{C} \text { age BP }\right]^{2}+1.2896 \times\left[{ }^{14} \mathrm{C}\right.$ age $\left.\mathrm{BP}\right]-1005$.

Table 2. AMS Carbon-14 dating results for ODP Hole 1202B. The conversion of ${ }^{14} \mathrm{C}$ age to calendar age was done using CALIB 4.4 (http:// radiocarbon.pa.qub.ac.uk/calib/).

\begin{tabular}{llclll} 
Sample ID & Material & Depch (mbsh) & ${ }^{14}$ C year BP & Margin & Calendar year BP \\
\hline 1 H2W-36-47 & & & & & \\
$2 \mathrm{H} 6 \mathrm{~W}-34-46 \mathrm{~cm}+50-56$ & planktics & 10.88 & 3153 & 40 & 1295 \\
$3 \mathrm{H} 6 \mathrm{~W}-34-45.5+50-56$ & planktics & 20.48 & 5135 & 45 & 2886 \\
$4 \mathrm{HCC}$ & planktics & 31.35 & 8554 & 70 & 5486 \\
$5 \mathrm{H} 6 \mathrm{~W}-40-56 \mathrm{~cm}$ & planktics & 39.35 & 10205 & 55 & 8971 \\
$9 \mathrm{H} 6 \mathrm{~W}-40-56 \mathrm{~cm}$ & planktics & 77.35 & 13340 & 95 & 11074 \\
$10 \mathrm{H} 4 \mathrm{~W}$ & planktics & 83.79 & 17111 & 70 & 15111 \\
$10 \mathrm{HCC}$ & planktics & 88.35 & 18478 & 90 & 19753 \\
$11 \mathrm{H} 6 \mathrm{~W}-40-50$ & planklics & 96.35 & 19810 & 100 & 21328 \\
$12 \mathrm{H} 3 \mathrm{~W}-40-56$ & planktics & 101.38 & 20910 & 120 & 22859 \\
$13 \mathrm{H} 4 \mathrm{~W}$ & planktics & 109.1 & 23430 & 140 & 24998 \\
\hline
\end{tabular}

\section{Stable Isotope Analysis of Planktic Foraminifera}

Specimens of Neogloboquadrina dutertrei, a thermocline-dwelling planktic foraminifera, were picked the 355 425 $\mu$ size fraction were picked for oxygen and carbon isotopic analyses. Cleaned specimens were reacted with phosphoric acid at $90^{\circ} \mathrm{C}$ in the heating block of the Micromass MultiCarb automation system. The $\mathrm{CO}_{2}$ gas generated was analyzed using a Micromass IsoPrime isotope ratio mass spectrometer housed in the Department of Earth Sciences, National Taiwan Normal University. The carbonate standard NBS-19 was used to calibrate to the Peedee belemnite (PDB) standard. The average precision of the NBS standard analyzed was $0.03 \%$ for $\delta^{13} \mathrm{C}$ and $0.08 \%$ for $\delta^{18} \mathrm{O}(\mathrm{N}=113)$. 


\section{RESULTS AND DISCUSSION}

\section{Age Model and Sedimentation Rates of ODP1202B}

The depth-age relationship of Hole 1202B is well constrained by the 11 carbon-14 dating points (Fig. 5A). The sedimentation rates are relatively high, varying between 1.5 and $9 \mathrm{~m} \mathrm{kyr}^{-1}$. Such high sedimentation rates are unprecedented in the Okinawa Trough and somewhat unexpected. Previous published results from southern Okinawa Trough sites recorded sedimentation rates of about $50 \mathrm{~cm} \mathrm{kyr}^{-1}$. For instance, Site RN96-PC 1 at $24^{\circ} 58.5^{\prime} \mathrm{N}, 122^{\circ} 56.1^{\prime} \mathrm{E}$ records an average rate of $40 \mathrm{~cm} \mathrm{kyr}^{-1}$ (Ujiié et al. 2003) while at a northern site, Core $255\left(25^{\circ} 12^{\prime} \mathrm{N}\right.$, $123^{\circ} 07^{\prime} \mathrm{E}$ ) has an average rate of $60 \mathrm{~cm} \mathrm{kyr}^{-1}$ for the last $8 \mathrm{kyr}$ (Jian et al. 2000). For the similar time interval of the last $20 \mathrm{kyr}$, Hole 1202B has accumulated 30 meters of sediment, showing an average sedimentation rate almost one order higher than other sites. The large accumulation of sediments at this site suggests that Hole 1202B is located at a localized deposition center. The sediments are mainly composed of fine terrestrial clay and silt. The coarsesized fraction $(>63 \mu)$, made up chiefly of foraminfers, only accounts for 1 to $6 \%$ of the sediments (Fig. $5 \mathrm{C}$ ). The percentage of coarse fraction decreased to less than $1 \%$ in the intervals with the highest sedimentation rate $\left(\sim 9 \mathrm{~m} \mathrm{kyr}^{-1}\right)$ from 11 to $15 \mathrm{ka}$ (Figs. 5B and C). The scarcity of foraminifers in this interval due to dilution by enormous terrestrial material has caused difficulty in obtaining enough specimens for $\mathrm{C}-14$ dating and isotopic analysis.

\section{Correlation between Hole 1202B and 1202D}

The upper $0-80 \mathrm{~m}$ of the Holes 1202B and 1202D can be well correlated based upon lithologic marker beds and magnetic susceptibility variation (Figs. 3 and 4). Recovery breaks in the lower section of Hole 1202D makes the record fragmentary and difficult to correlate with Hole 1202B. Nevertheless, all the five discontinuously recovered intervals in Hole 1202D between 85 and $125 \mathrm{mbsf}$ show high bulk density, conceivably of silt and clay in component. These beds are correlated with the high-density counterparts in Hole 1202B (Fig. 4). As a result, 18 tie points are recognized, and an age model has been built for the top $140 \mathrm{~m}$ of Hole 1202D (Table 1).

\section{Biostratigarphic Constrains of Hole 1202D}

The age-diagnostic marker for nannofossil Zone NN21, Emiliania huxleyi, occurs persistently throughout the sequence, suggesting that the drilled sequence is younger than $0.25 \mathrm{Ma}$ (Berggren et al. 1995; Nash et al. 1998). Furthermore, the relative abundance of E. huxleyi is comparable to that of Gephyrocapsa oceanica throughout the sequence ( $\mathrm{Su}$ and Wei 2005), suggesting that the bottom of Hole 1202D is still within the acme zone of E. huxleyi. The age of the bottom of the acme zone in the Pacific has been dated to be at $85 \mathrm{ka}$ (Berggren et al. 1995). The absence of pink Globigerinoides ruber, on the other hand, delimits the sequence to be younger than $127 \mathrm{ka}$ (Lee et al. 1999; Wei et al. 2000). Moreover, the persistent appearance of orange-colored tiny Zeaglobigerina rubescens indicates that the sediments recovered are young and fresh (Parker and Berger 1971). 


\section{ODP1202B}

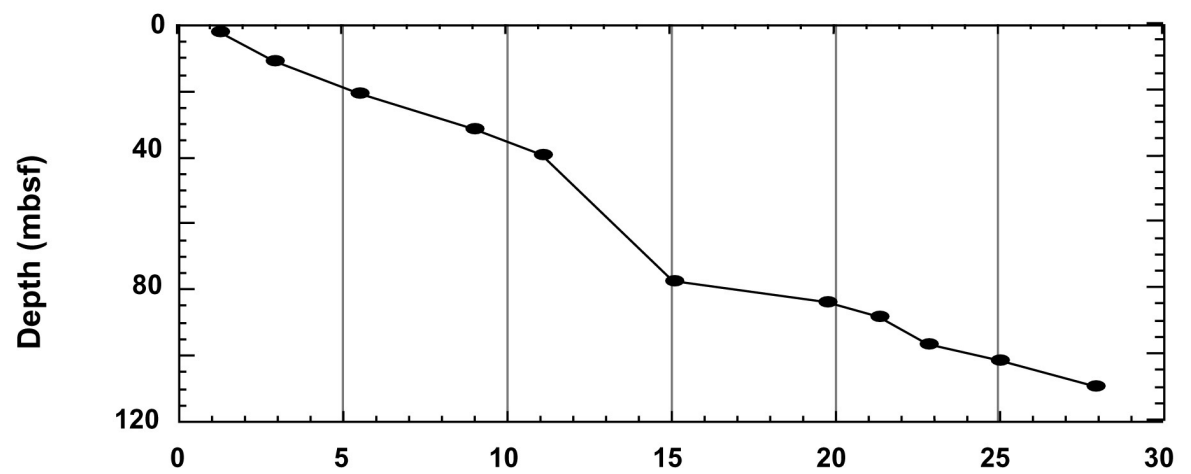

$A$
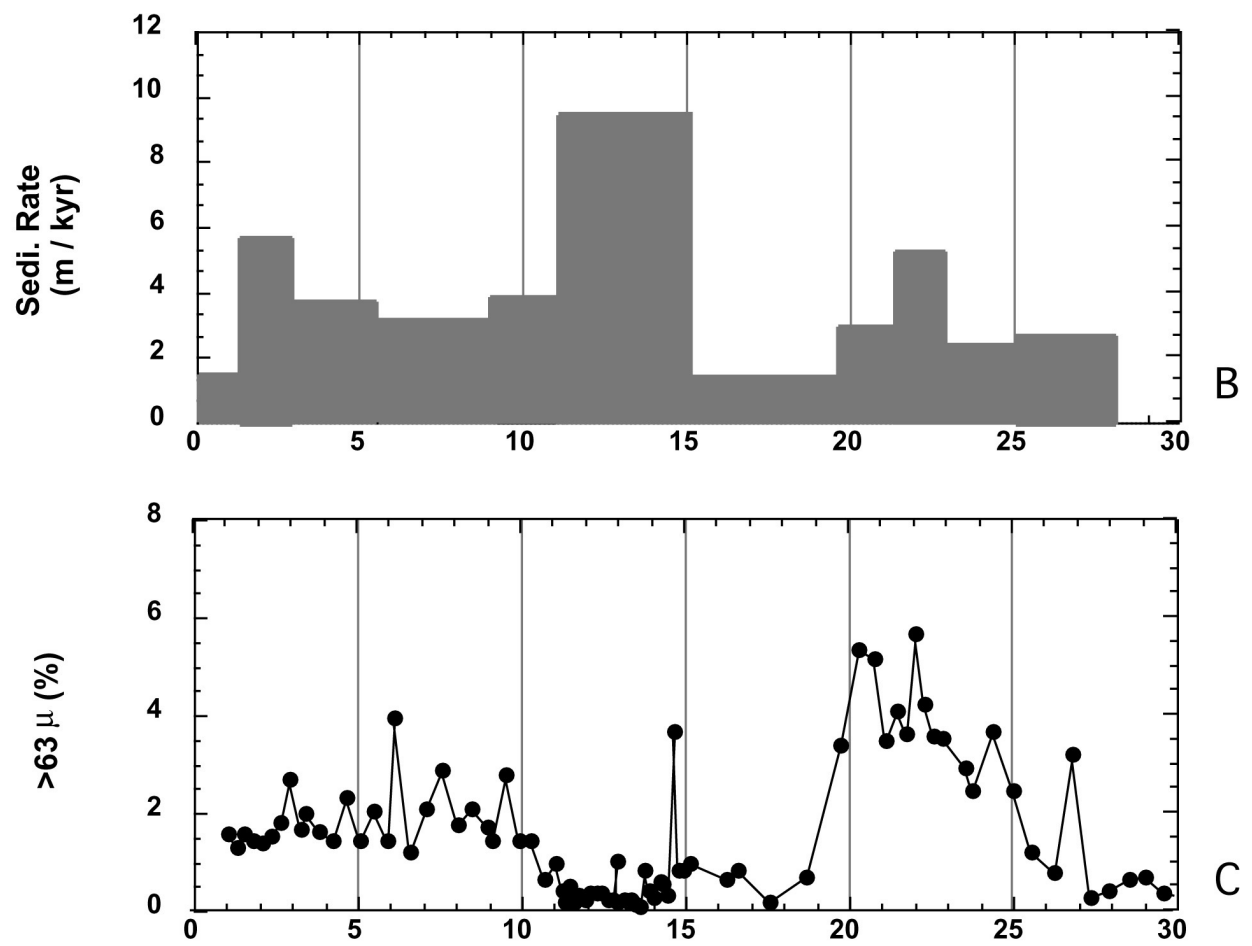

Age (ka)

Fig. 5. (A) Depth-age relationship of Hole 1202B based upon AMS carbon-14 dating of 11 samples. (B) Sedimentation rates of the upper $110 \mathrm{~m}$ of Hole 1202B. (C) Variation in percentage of coarse size fraction $(>63 \mu)$ through the last $30 \mathrm{kyr}$ in Hole 1202B. 


\section{Oxygen Isotope Stratigarphy}

Oxygen isotope stratigraphy provides another reliable means for correlation and age assignment. Figure 6 shows a stacked profile of oxygen isotopic ratio compiled from Holes 1202B and 1202D, with correlation lines with the $\delta^{18} \mathrm{O}$ profile of DGKS9603 generated from the same species, $N$. dutertrei, in a central Okinawa Trough site (Li et al. 2002). As assisted by dense AMS carbon-14 dating in both cores, the oxygen isotope profiles of the past $35 \mathrm{kyr}$ shows an excellent match between the two sites (Fig. 7). Profiles of carbon isotopes also show good agreement between the two sites except for the lower most sections (Fig. 7).

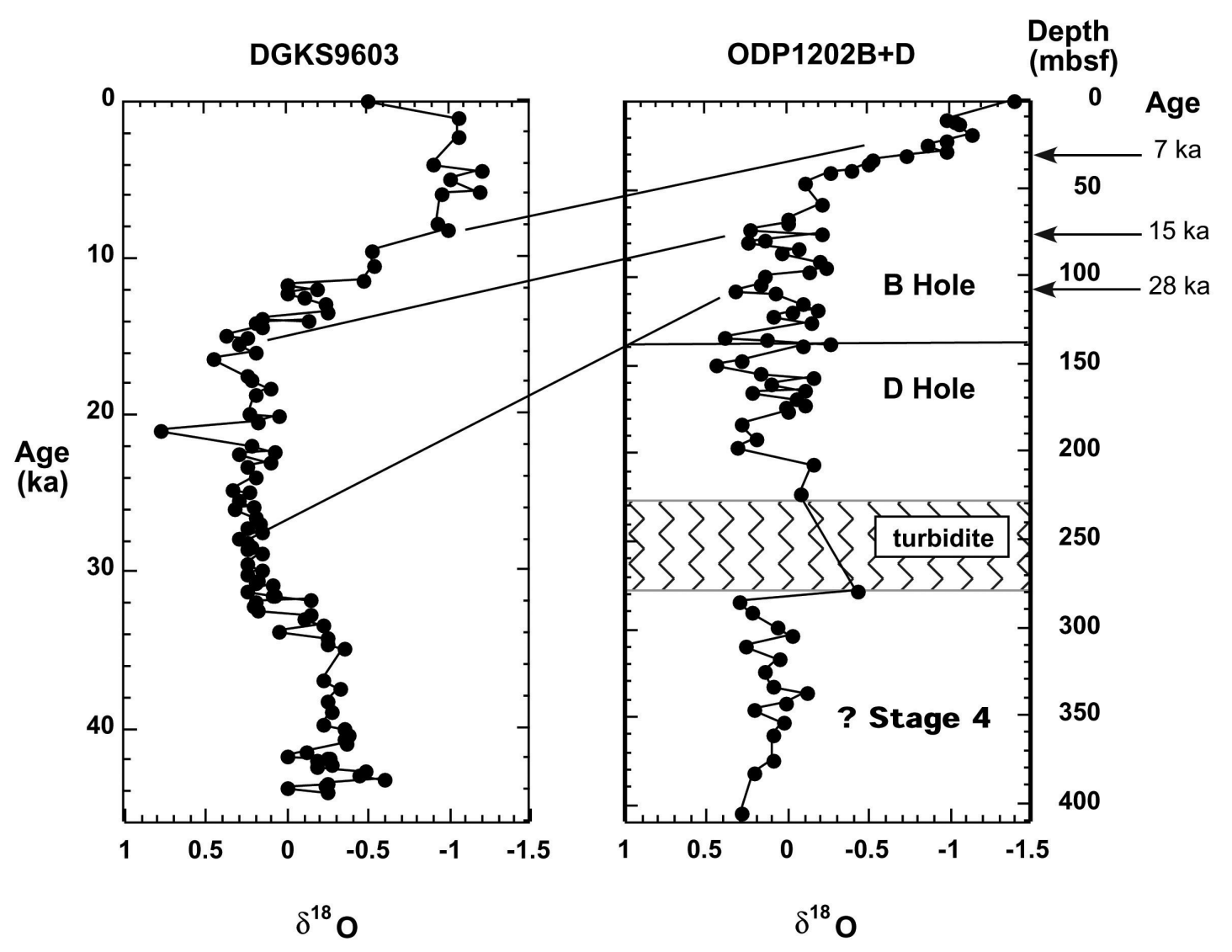

Fig. 6. Oxygen isotopic profiles of Site DGKS9603 and ODP 1202. Both profiles are generated from the same species, Neogloboquadrina dutertrei but from different size fractions. For Site DGKS, the foraminiferal specimens are from $300-355 \mu$ (Li et al. 2001), whereas that of Hole 1202 are from $355-425 \mu$. Correlation between these two sites in the upper sections is aided by AMS C-14 dating of both sequences. 


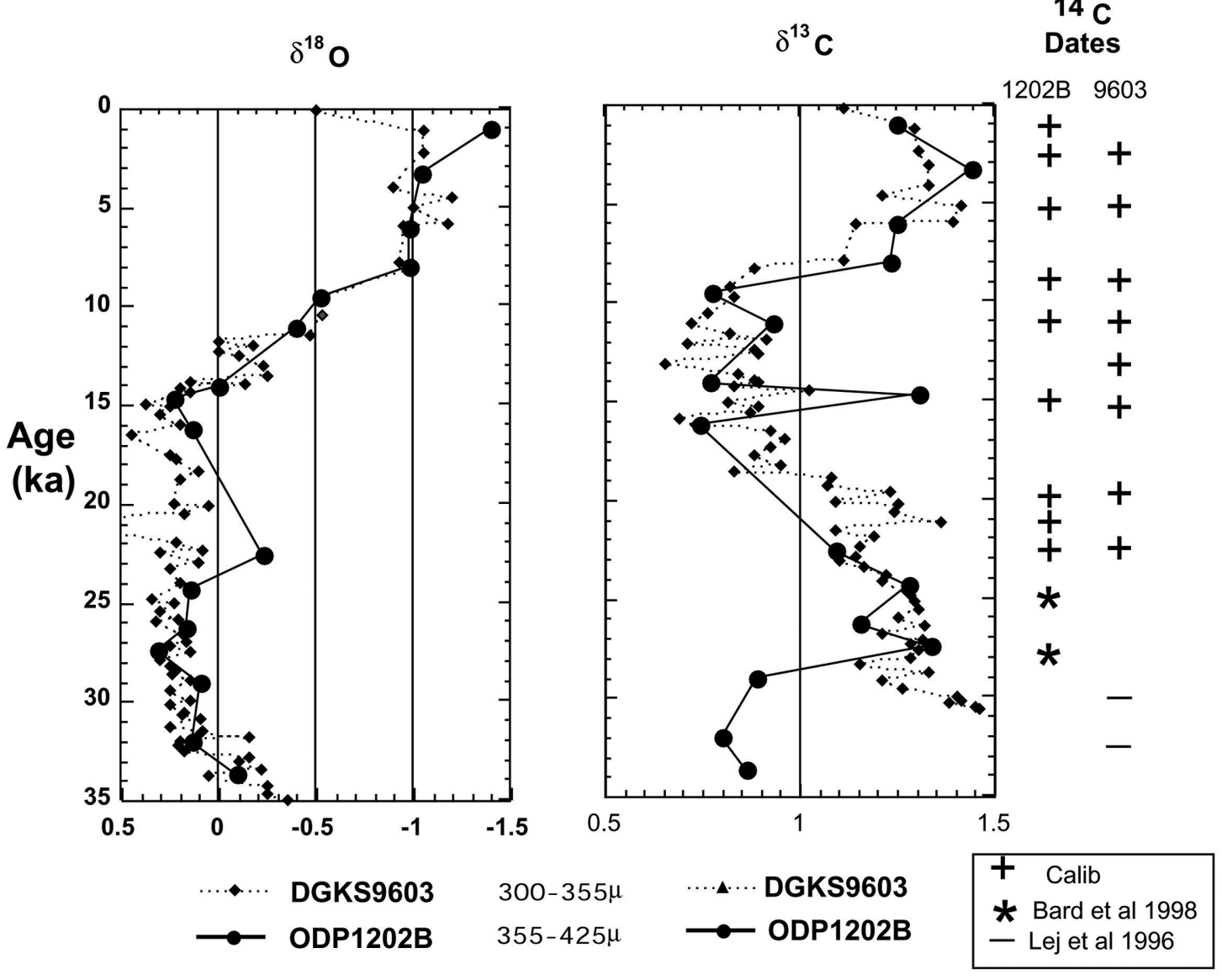

Fig. 7. Time-series of oxygen and carbon isotopic variation in Hole 1202B and DGKS9603. The oxygen isotope data of DKGS9603 are from Li et al (2001) while the carbon isotope data are from Li et al. (2002). Both sequences are furnished with many AMS C-14 dates converted to calendar year before present. The AMS C-14 dating points are marked by + . Note that the calendar age conversion for C-14 ages older than 25,000 years in Core DKGS9603 was done based upon Lej et al. (1996).

The lower sections in Hole 1202D are hard to correlate with that of DGKS9603, partly due to the lack of distinctive characteristics in the profiles and partly due to the sedimentary break caused by the "turbidite" between 230 and $280 \mathrm{mbsf}$ (Fig. 6). The $\delta{ }^{18} \mathrm{O}$ values in the interval between 140 - 228 mbsf are comparable to that of the lower part of Hole 1202B, presumably being of marine oxygen isotope stages (MIS) 2 and 3 (Fig. 6). On the other hand, the $\delta^{18} \mathrm{O}$ values of the lower part (below the "turbidite" interval) are still in the same range of positive values, and cannot be correlated with the lower part of Site DGKS9603. As con- 
strained by nannofossil and planktic foraminiferal biostratigarphic evidence (discussed in the previous section), the bottom of Hole 1202D cannot be older than $85 \mathrm{ka}$. This brackets the questioned section to be in the range of MIS 4.

To further determine the age for Hole 1202D (280 - $410 \mathrm{mbsf}$ ), we did a wiggle matching of the $\delta^{18} \mathrm{O}$ profile with that of $G$. ruber generated from Site MD972142 in the South China Sea (Wei et al. 2003) and the result is shown in Fig. 8. The upper sections (138 to $207 \mathrm{mbsf}$ ) of Hole 1202D are correlated to MIS 3 with an age assignment of 33.7 to $39.7 \mathrm{ka}$ while the lower part (278 to $406 \mathrm{mbsf}$ ) is correlated with MIS 4 between 52 and $68 \mathrm{ka}$ (Table 3). The correlation is somewhat tentative, because the two species that yielded the oxygen isotopic signals have dwelled in different levels of the water column, and the hydrological conditions of the Okinawa Trough are not necessarily the same as that in the South China Sea. However, for the time being, the lack of comparable $\delta^{18} \mathrm{O}$ record generated from $N$. dutertrei from Asian subtropical waters hinders a more decisive correlation.

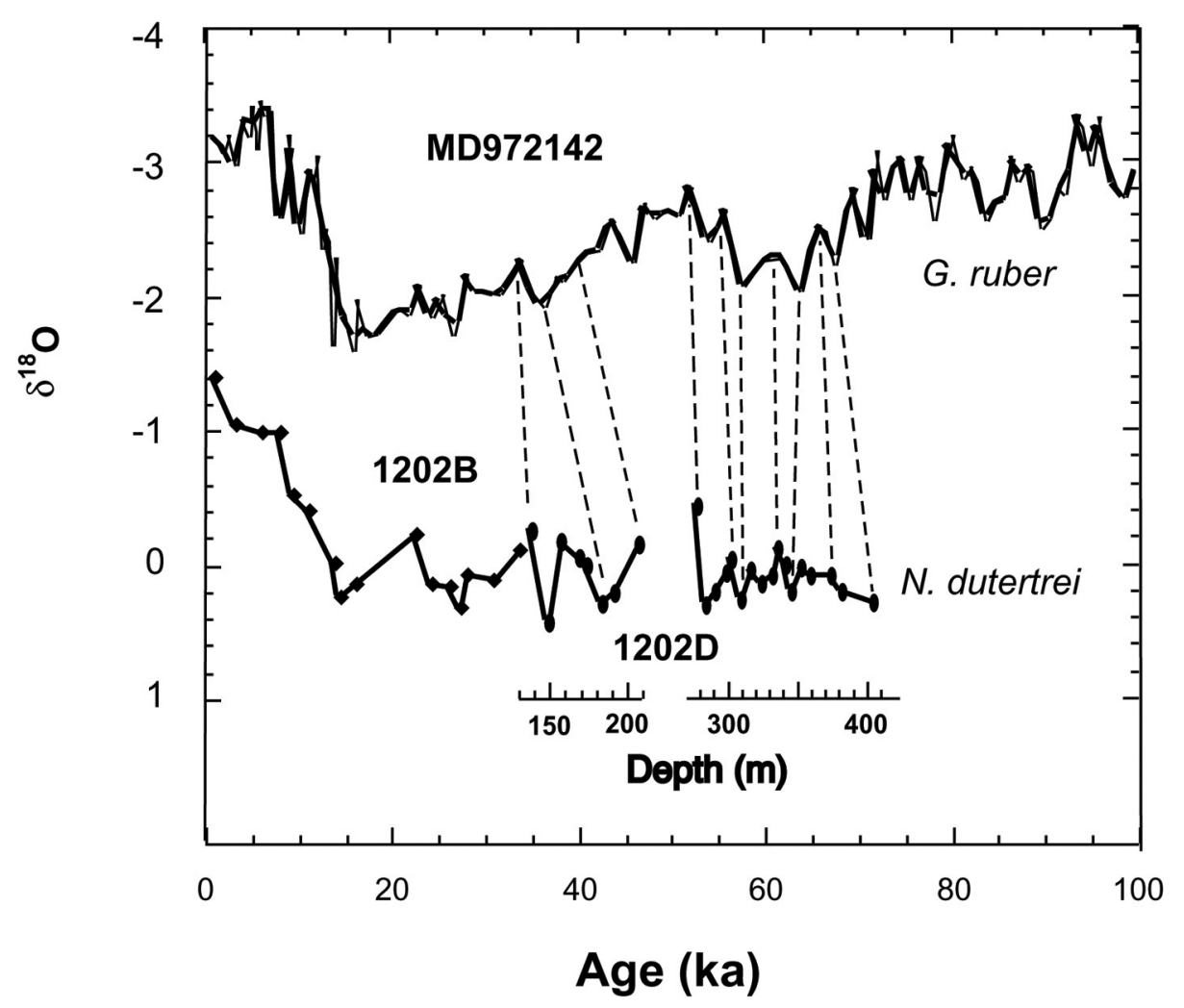

Fig. 8. Correlation of oxygen isotopic profiles between Hole 1202 and MD972142 (Wei et al. 2003). The bold curve of MD972142 represents the moving average of the raw data represented by the thin lines. 
Table 3. Depth-age relationship in Hole 1202D.

\begin{tabular}{ll} 
Depth (m) & Age (ka) \\
& \\
2.86 & 1.60 \\
11.44 & 3.05 \\
16.10 & 4.33 \\
20.90 & 6.10 \\
21.08 & 6.23 \\
26.04 & 7.61 \\
29.92 & 8.60 \\
40.00 & 11.36 \\
48.78 & 12.21 \\
62.00 & 13.65 \\
64.80 & 13.94 \\
73.20 & 16.01 \\
79.56 & 20.18 \\
87.80 & 22.43 \\
99.20 & 27.53 \\
107.20 & 30.97 \\
138.80 & 33.70 \\
184.00 & 36.45 \\
207.32 & 39.73 \\
278.60 & 52.00 \\
310.50 & 57.84 \\
336.40 & 62.05 \\
346.10 & 64.00 \\
405.50 & 67.56 \\
& \\
\hline
\end{tabular}

\section{Age model for ODP Site 1202}

Furnished by various means of stratigraphic correlation and age determination, Holes $1202 \mathrm{~B}$ and $1202 \mathrm{D}$ can be correlated, dated and stacked. The resultant $\delta{ }^{18} \mathrm{O}$ profile plotted against age is presented in the bottom panel of Fig. 9. The sedimentation rates are generally high throughout the record, ranging from $\sim 2$ to $16 \mathrm{~m} \mathrm{kyr}^{-1}$. The extremely high rates calculated for the uppermost and lowermost sections of Hole 1202D might be erroneous as they are poorly correlated. However, one could confidently conclude that the sequence generally reflects high accumulation rates, with an average of $\sim 5 \mathrm{~m} \mathrm{kyr}^{-1}$. The sediments are composed 


\section{ODP 1202}
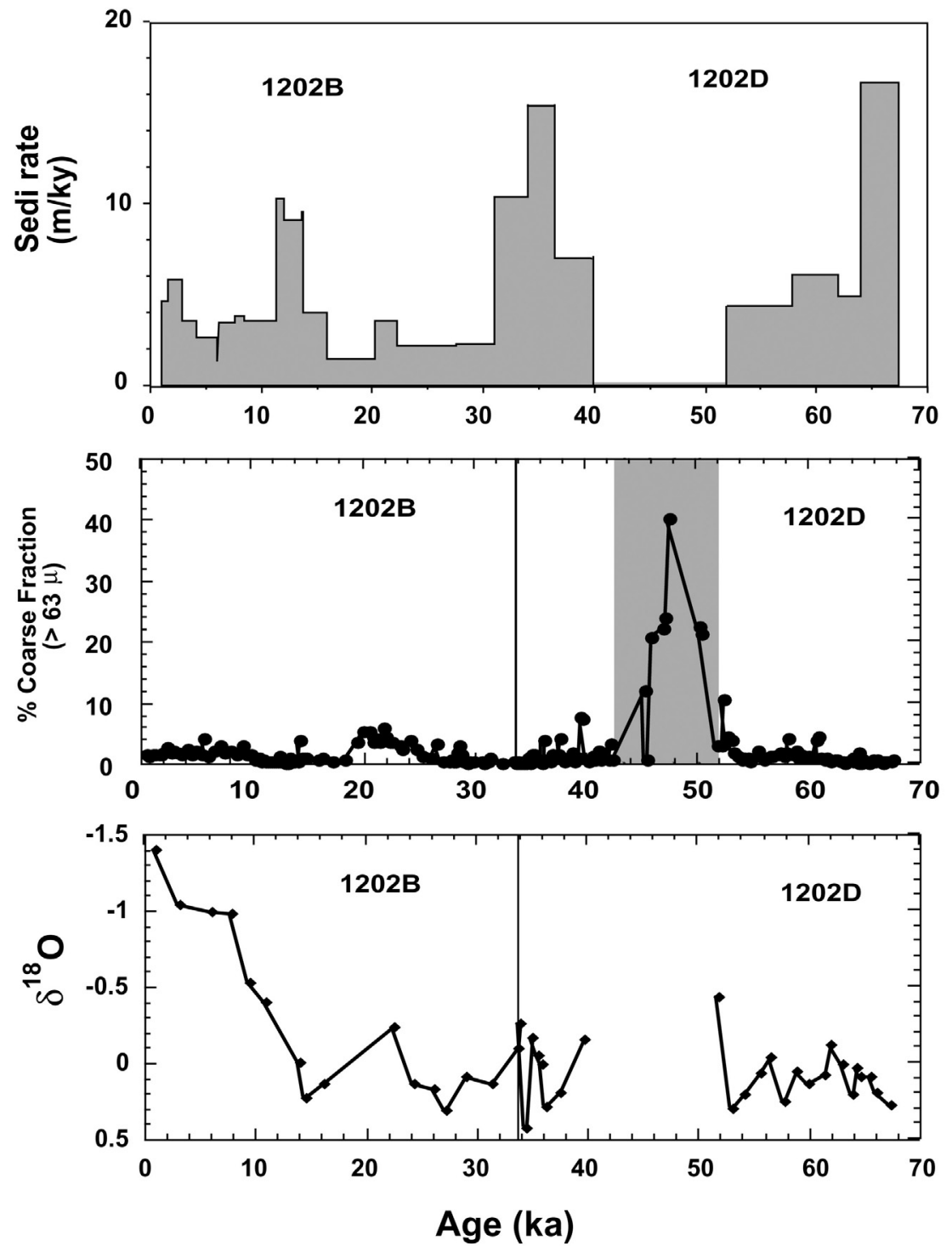

Fig. 9. Upper panel: Sedimentation rates of the past $68 \mathrm{kyr}$ of Hole 1202D. The depth-age pairs for the age model are listed in Table 3. Middle: Percentage of coarse fraction $(>63 \mu)$ of Hole 1202B and 1202D. The shaded pattern marks the interval of high abundance of sandy particles in the middle section of Hole 1202D, implying the occurrence of turbidites during 42 to $52 \mathrm{ka}$. Lower panel: Stacked oxygen isotopic profiles of Holes 1202B and $1202 \mathrm{D}$. 
mainly of fine terrestrial silt and clay. The only exception is the interval between 230 - $280 \mathrm{mbsf}$, consisting with coarse sandy particles (Fig. 9). This interval is probably of turbidite origin (Huang et al. 2005). The high amount of accumulation of terrestrial sediments at this site has contributed to an extremely high-resolution record; however, it has significantly diluted microfossil components.

\section{SUMMARY}

Despite its deep penetration of Site 1202, the recovered sedimentary sequence appears to record only the very last of the Quaternary - the last 70 thousand years or so.

The AMS C-14 dating of biogenic carbonates picked from 11 intervals down to $110 \mathrm{mbsf}$ allows constructing an adequate chronological framework for the last 28 thousand years. The average sedimentation rate of the topmost 110 meters of the record is about $4.2 \mathrm{~m} \mathrm{kyr}^{-1}$, a rate of an order higher than that reported previously from the neighboring sites in the southern Okinawa Trough.

The interval from 230 280 mbsf is of poor recovery, and the recovered sediments are sandy, marked by high percentage of coarse sediments $(>63 \mu)$. This $\sim 50 \mathrm{~m}$ interval is apparently a turbidite dominated interval, deposited presumably somewhere between 40 and $52 \mathrm{ka}$ (Fig. 9, Table 3). The bottom of Hole 1202D is still younger than marine oxygen isotope stage 5 .

Acknowledgements We thank the curators of the Ocean Drilling Program for making samples available. The magnetic susceptibility and density were measured by Dr. Dave Hart and Dr. Simon M. Dean onboard Leg 195. Assistance and facility offered by the ODP Gulf Repository, Texas A \& M University, during post-cruise sampling and lithologic examination sessions were particularly helpful. Foraminifera picking and isotopic analyses were conducted by Ms. Ee-Ee Teh. This work was supported by the Ocean Drilling Program of National Science Council, R.O.C. (NSC 90-2611-M-002-005-ODP; NSC 91-2611-M-002-019).

\section{REFERENCES}

Berggren, W. A., F. J. Hilgen, C. G. Langereis, D. V. Kent, J. D. Obradovich, I. Raffi, M. E. Raymo, and N. J. Shackleton, 1995: Late Neogene chronology: new perspectives in high-resolution stratigraphy. Geol. Soc. Am. Bull., 107, 1272-1287.

Hideshima, S., E. Matsumoto, O. Abe, and H. Kitagawa, 2001: Northwest Pacific marine reservoir correction estimated from annually banded coral from Ishigaki Island, southern Japan. Radiocabon, 43, 473-476.

Huang, C. Y., Y. L. Chiu, and M. Zhao, 2005: Core description and preliminary sedimentological study of Site 1202D, Leg 195, in the southern Okinawa Trough.Terr. Atmos. Ocean. Sci., 16, 19-44.

Jian, Z., P. Wang, Y. Saito, J. Wang, U. Pflaumann, T. Oba, and X. Cheng, 2000: Holocene variability of the Kuroshio Current in the Okinawa Trough, northwestern Pacific Ocean. Earth Planet. Sci. Lett., 184, 305-319. 
Laj, C., A. Mazaud, J. C. Duplessy, 1996: Geomagnetic intensity and ${ }^{14} \mathrm{C}$ abundance in the atmosphere and ocean during the past 50 kyr. Geophys. Res. Lett., 23, 2045-2048.

Lee, M. Y., K. Y. Wei, and Y. G. Chen, 1999: High resolution isotope stratigraphy for the last 150,000 years in the southern South China Sea: Core MD972151.Terr. Atmos. Ocean. Sci., 10, 239-254.

Li, T., Z. Liu, M. A. Hall, S. Berne, Y. Saito, S. Cang, and Z. Cheng, 2001: Heinrich event imprints in the Okinawa Trough: evidence from oxygen isotope and planktonic foraminifera. Palaeogeog., Palaeoclimatol., Palaeoecolog., 176, 133-146.

Li, T., Z. Liu, M. A. Hall, Y. Saito, S. Berne, S. Cang, and Z. Cheng, 2002: A broad deglacial $\delta{ }^{13} \mathrm{C}$ minimum event in planktonic foraminiferal records in the Okinawa Trough. Chinese Sci. Bull., 47, 599-603.

Naish, T., S. Abbott, B. Alloway, A. Beu, R. Carter, A. Edwards, T. Journeaux, P. Kamp, B. Pillans, G. Saul, and K. Woolfe, 1998: Astronomical calibration of a southern hemisphere Plio-Pleistocene reference section, Wanganui Basin. N. Z.Quat. Sci. Rev., 17, 695-710.

Parker, F. L., and W. H. Berger, 1971: Faunal and solution pattern of planktonic foraminifera in surface sediments of the South Pacific.Deep-Sea Res., 18, 73-107.

Shipboard Scientific Party, 2002: Site 1202. In Salisbury, M.H., Shinohara, M., Richter, C., et al., Proc. ODP, Init. Repts., 195, 1-46 [CD-ROM]. Available from: Ocean Drilling Program, Texas A\&M Univ., College Station TX 77845-9547, USA.

$\mathrm{Su}, \mathrm{X}$., and K. Y. Wei, 2005: Calcareous nannofossils and variation of Kuroshio Current in the Okinawa Trough during the last 13000 years. Terre. Atmos. Ocean. Sci., 16, 95111.

Ujiié, Y., H. Ujiié, A. Taira, T. Nakamura, and K. Oguri, 2003: Spatial and temporal variability of surface water in the Kuroshio source region, Pacific Ocean, over the past 21,000 years: evidence from planktonic foraminifera. Marine Micropaleontol., 49, 335-364.

Wei, K. Y., T. C. Chiu, and Y. G. Chen, 2000: Planktic foraminiferal oxygen isotope record of the last 350 thousand years of Core MD972142, southeastern South China Sea: Chronostratigraphy, orbital forcing and paleoceanographic implications.J. Geo. Soc. China, 43, 393-408.

Wei, K. Y., T. C. Chiu, and Y. G. Chen, 2003: Toward establishing a maritime proxy record of the East Asian summer monsoons for the Late Quaternary. Marine Geol., 201, 6779. 